\title{
Direct and Indirect Effect of Bt Cotton and No Bt Cotton on the Development and Reproduction of the Predator Podisus nigrispinus (Dallas, 1851) (Hemiptera: Pentatomidae)
}

\author{
Alexa G. Santana1, Crébio J. ÁVila ${ }^{2 *}$, Harley N. de Oliveira², Patrícia P. Bellon³, \\ Eunice C. Schlick-Souza1 \\ ${ }^{1}$ (DCR)-Embrapa Agropecuária Oeste, Dourados, Brasil \\ ${ }^{2}$ Embrapa Agropecuária Oeste, Dourados, Brasil \\ ${ }^{3}$ Entomology and Biodiversity Conservation Grande Dourados Federal University (UFGD), Dourados, Brasil \\ Email: euniceschlick@hotmail.com, *crebio.avila@embrapa.br
}

How to cite this paper: Santana, A.G., ÁVila, C.J., de Oliveira, H.N., Bellon, P.P. and Schlick-Souza, E.C. (2017) Direct and Indirect Effect of Bt Cotton and Conventional Cotton on the Development and Reproduction of the Predator Podisus nigrispinus (Dallas, 1851) (Hemiptera: Pentatomidae). American Journal of Plant Sciences, 8, 1438-1448. https://doi.org/10.4236/ajps.2017.86098

Received: April 1, 2017

Accepted: May 24, 2017

Published: May 27, 2017

Copyright (c) 2017 by authors and Scientific Research Publishing Inc. This work is licensed under the Creative Commons Attribution International License (CC BY 4.0).

http://creativecommons.org/licenses/by/4.0/

\begin{abstract}
This paper aimed to evaluate the direct and indirect effects of Bt cotton and no Bt cotton on the development and reproduction of the predator Podisus nigrispinus (Dallas). The experiments related to the direct and indirect effects on immature and adult stages of the predator were conducted, respectively, in greenhouse and laboratory of the Embrapa Agropecuária Oeste in Dourados, Mato Grosso do Sul State, Brazil. To evaluate the indirect effects of Bt cotton and non-Bt, larvae of Spodoptera frugiperda (Smith) were fed with these plants and later offered to the predator. To evaluate the direct effect of the Bt cotton and non-Bt, the predator $P$. nigrispinus was kept in contact with these plants and fed with pupae of Tenebrio molitor (L.). The direct and indirect effects were evaluated by the biological parameters as follows: period of nymphal development, nymphal survival, and duration of pre-oviposition and oviposition periods and longevity of adults (females and males) of $P$. nigrispinus. It was observed higher period of second instar of $P$. nigrispinus in Bt cotton, when compared to the development in its isoline non-Bt. All other biological parameters evaluated, have no influence of the Bt cotton plants considering the direct and indirect effects.
\end{abstract}

\section{Keywords}

Bt Plants, Natural Enemy, Survival 


\section{Introduction}

The cultivation of transgenic plants has increased considerably in recent years in Brazil and the world, and still has potential for expansion due to the innumerable benefits this technology has brought to production systems and the environment. Brazil occupies the second place worldwide with areas planted with these technologies, and is considered a global leader in biotechnological plantations [1] [2].

Genetically modified plants that contain genes introduced by genetic engineering to control insects, encode Bt proteins from Bacillus thuringiensis Berliner, which may have effective insecticidal action on insects, especially from the orders Lepidoptera and Coleoptera [3]. Among the main plant species that express Bt proteins, the cultivation of cotton, soybean and corn crops stand out [4] [5] [6], with the different groups of Bt proteins being specially directed to the control of defoliator caterpillars in the crops. These proteins or toxins, as they are also called, can be transferred directly or indirectly to other non-target arthropods such as bedbugs, aphids, whiteflies, thrips and mites that are normally insensitive to $\mathrm{Bt}$ toxins or even to natural enemies, especially predators and parasitoids [4] [7]. The poisonous effects of Bt toxins on non-target organisms, especially the extent to which these toxins move through the different trophic levels, have been relatively very understudied [8]. [6] found that the Bt CrylAc toxin that is used in transgenic cotton cultivars can be transmitted from the aphid Aphis gossypii (Glover) to the predator Propylaea japônica (Thunberg) and change its biology and predation behavior. The acquisition of these toxins by arthropod predators in direct or indirect form of transgenic plants, may or may not cause changes in their biology or predation capacity [9] [10] [11].

Predators of the genus Podisus (Hemiptera: Pentatomidae) are often found in several agricultural systems, where they act by feeding on various insect species on immature and adult forms [12] [13]. This group of predators can be directly affected by plants that express Bt proteins, when they have the habit of sucking parts of these plants to obtain water and minerals or even indirectly, by feeding on those prey that have previously developed in these transgenic plants [14] [13]. Therefore, it is extremely important to analyze the possible risks arising from the adoption of genetically modified organisms in the agricultural systems environments. These elements of this discussion depend on the availability of consistent scientific information that may or may not explain the poisonous effects of the proteins present in these transgenic materials without special about natural insect-pests enemies such as predators and parasitoids present in agricultural ecosystems [14].

This work aimed to evaluate the direct and indirect effect of Bt cotton and no Bt cotton on the predator P. nigrispinus reproduction and development.

\section{Materials and Methods}

The experiments involving the direct and indirect effect of Bt cotton and no Bt cotton plants on the immature and adult stages of the predator $P$. nigrispinus 
were conducted respectively in a greenhouse and in the Laboratory of Entomology of the Embrapa Agropecuária Oeste in Dourados/MS.

Seeds of Bt cotton (cv. Bollgard $\mathrm{NuOpal}^{\circledR}$ ) that expressed the Cryl Ac protein) and of no Bt cotton ( $\mathrm{cv}$. Delta-Opal ${ }^{\triangleright}$ ) were seeded in a $5 \mathrm{~L}$ soil capacity polyethylene pots containing a mixture of soil and compost in the proportion of 1:1. After thinning, only two Bt and no Bt cotton plants were conducted per pot, which were irrigated when necessary.

\subsection{Direct Effect of Bt Cotton and No Bt Cotton Plants on the Im- mature And adult Stage of $P$. nigrispinus}

To evaluate the direct effect of cotton plants on the immature stage of $P$. nigrispinus, predator second instar nymphs, up to 24 hours old, were individualized in the third or fourth cotton leaf developed from the apex of the plant, since this predator has the life style of sucking parts of these plants to obtain water and minerals. The nymphs were kept inside cylindrical PVC cages, measuring $1.5 \mathrm{~cm}$ in height and $4 \mathrm{~cm}$ in diameter, with the upper part closed with a voile-like fabric and the other basal end in direct contact with the cotton leaf.

The nymphs in direct contact with cotton leaves were fed every two days with Tenebrio molitor (L.) pupae throughout the predator nymph development period, both in Bt cotton and no Bt cotton plants. The PVC cages were monitored daily to register the presence of exuviae (insect skin exchange), the duration and viability of each nymph stage, as well as the duration and total viability of the immature stage of the predator.

Predator adults from breeding during the nymphal stage with T. molitor pupae and in direct contact with both Bt cotton and no Bt cotton were used to evaluate the direct effect of cotton at this stage. For this, 20 predator couples were formed using insects up to 24 hours old, which were confined in cylindrical PVC cages and fixed in the cotton leaves, like it was done for the predator immature stage. T. molitor pupae were offered every two days as prey to the couples throughout the predator adult stage in direct contact with the cotton plants. Every two days, the clusters were removed, and the eggs were counted and conditioned in Petri plates containing cotton soaked in distilled water for the hatching of the nymphs. The pre-oviposition period, oviposition, total fecundity and longevity of adults (males and females) of the predator were evaluated. It was evaluated the duration (days) and nymphal viability (\%), the periods of pre-oviposition (PP) and oviposition (PO), the total fertility (FT), the longevity of males (LM) and females (LF), and the fecundity of P. nigrispinus

The experiments were conducted in a completely randomized design, with two treatments (Bt cotton and no Bt cotton), with 30 replicates (PVC cage containing a predator nymph) for the immature stage trial and 20 replicates (PVC cage containing a predator couple) for the predator's adult stage trial.

\subsection{Indirect Effect of Bt Cotton and No Bt Cotton Plants on the Immature and Adult Stages of $P$. nigrispinus}

To evaluate the indirect effect of $\mathrm{Bt}$ cotton and no Bt cotton plants on the pre- 
dator immature stage, 30 second-instar $P$. nigrispinus nymphs of the rearing of this predator in the laboratory, were used, with up to 24 hours old. Nymphs were individualized in Petri plates $(9.0 \times 1.5 \mathrm{~cm})$ containing on the bottom of the cotton soaked in distilled water. Second-instar $S$. frugiperda caterpillars, raised on an artificial bean-based diet, were placed in plastic trays containing Bt (Bollgard $\mathrm{NuOpal}^{\circledR}$ ) cotton or no $\mathrm{Bt}\left(\right.$ Delta Opal $\left.^{\oplus}\right)$ cotton leaves. The caterpillars remained feeding on the cotton leaves (Bt and conventional) for 48 hours until they were about $2.5 \mathrm{~cm}$ in length. After this feeding period, the caterpillars were offered every two days to the P. nigrispinus nymphs that were in the Petri plates, throughout the predator's immature stage. Petri plates were monitored daily to register the presence of exuviae (insect skin exchange), the duration and viability of each nymphal stage, as well as the duration and total viability of the predator immature stage.

Predator adults from breeding during the nymphal stage with $S$. frugiperda caterpillars fed both with Bt cotton and no Bt cotton were used to evaluate the indirect effect at this stage. For this, 20 predator couples were formed using insects, with up to 24 hours old, which were placed in Petri plates containing cotton soaked in distilled water. Second-instar $S$. frugiperda caterpillars raised with an artificial bean-based diet were fed for 48 hours with $\mathrm{Bt}$ (Bollgard Nu-Opal ${ }^{\circledR}$ ) cotton and no Bt (Delta-Opal ${ }^{\oplus} \mathrm{cv}$.) cotton leaves, as performed on the immature stage and then offered, every two days, to the predator couples that were in the Petri plates. In this trial, only the longevity of predator males and females was determined.

The experiments were conducted in a completely randomized design with the two treatments (Bt and no Bt cotton), with 30 replicates (Petri plates containing a predator nymph) for the immature stage trial and 20 replicates (Petri plates containing a predator couple) for the predator's adult stage trial.

Data from both trials (direct and indirect effect on the predator immature and adult stages) were submitted to variance analysis, and when a significant treatment effect was found, the averages were compared by the $\mathrm{T}$ test with a $5 \%$ level of significance.

\section{Results}

\subsection{Direct Effect of Bt Cotton and No Bt Cotton Plants on the Im- mature and Adult Stages of $P$. nigrispinus}

It was observed a longer duration for the $P$. nigrispinus second instar when it was in direct contact with Bt cotton plants compared to the predator development period observed in no Bt cotton (Table 1). For all other instars, no significant differences were observed for the development periods when the predator was raised in direct contact with Bt cotton or no Bt cotton plants. There was also no significant difference in the viability of the four evaluated predator instars, which presented viability lower than $100 \%$ only for the second instar (Table 1).

Likewise, the pre-oviposition and oviposition periods, the total fecundity and 
$P$. nigrispinus adult males and females longevity did not differ when the predator was raised in direct contact with Bt cotton or no Bt cotton (Table 2). The fecundity of $P$. nigrispinus was also not significantly influenced by the direct contact of the predator with the Bt cotton in comparison to the insect raised in contact with no Bt cotton (Figure 1).

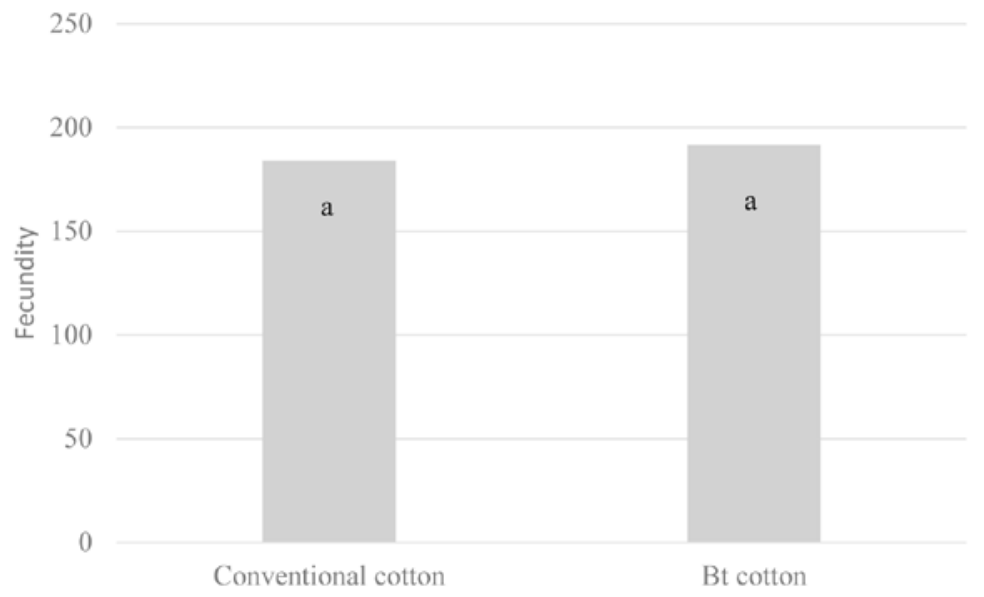

Figure 1. Fecundity of $P$. nigrispinus when reared with $T$. molitor and kept in direct contact with Bt cotton and no Bt cotton in greenhouse. Dourados, MS. Different letters represent significant differences among treatments by Tukey test $(p<0.05)$.

Table 1. Duration (days) and nymphal viability (\%) of $P$. nigrispinus when reared with $T$. molitor and kept in direct contact with $\mathrm{Bt}$ cotton and no $\mathrm{Bt}$ cotton, under greenhouse conditions. Dourados, MS.

\begin{tabular}{|c|c|c|c|c|c|}
\hline & \multicolumn{5}{|c|}{ Stages of development } \\
\hline Treatments & $2^{\circ}$ instar & $3^{\circ}$ instar & $4^{\circ}$ instar & $5^{\circ}$ instar & Total \\
\hline $\mathrm{Bt}$ & $4.25 \pm 0.30 \mathrm{a}$ & $4.00 \pm 0.24 a$ & $4.00 \pm 0.16 \mathrm{a}$ & $5.33 \pm 0.13 a$ & $17.17 \pm 0.43 a$ \\
\hline Conventional & $2.89 \pm 0.30 b$ & $4.18 \pm 0.24 a$ & $4.03 \pm 0.16 \mathrm{a}$ & $5.03 \pm 0.13 a$ & $16.15 \pm 0.43 a$ \\
\hline \multirow[t]{2}{*}{$\mathrm{CV}(\%)$} & 58.54 & 41.84 & 28.20 & 18.36 & 18.32 \\
\hline & \multicolumn{5}{|c|}{ Nymphal viability (\%) } \\
\hline Tratamentos & \multicolumn{2}{|c|}{$2^{\circ}$ instar } & ' instar & $4^{\circ}$ instar & $5^{\circ}$ instar \\
\hline $\mathrm{Bt}$ & \multicolumn{2}{|c|}{$80 \pm 7.43 a$} & $100 a$ & $100 \mathrm{a}$ & $100 \mathrm{a}$ \\
\hline Conventional & \multicolumn{2}{|c|}{$90 \pm 5.57 a$} & $100 \mathrm{a}$ & $100 \mathrm{a}$ & $100 \mathrm{a}$ \\
\hline
\end{tabular}

Different letters represent significant differences among treatments by Tukey test $(p<0.05)$

Table 2. Periods of pre-oviposition (PP) and oviposition (PO), total fertility (FT) and longevity of males (LM) and females (LF) of P. nigrispinus when reared with T. molitor and kept in direct contact with Bt cotton and no Bt cotton under greenhouse conditions. Dourados, MS.

\begin{tabular}{cccccc}
\hline Treatments & PP (dias) & PO (dias) & FT & LF (dias) & LM (dias) \\
\hline Bt & $9.3 \pm 1.65 \mathrm{a}$ & $24.80 \pm 3.63 \mathrm{a}$ & $41.23 \pm 6.62 \mathrm{a}$ & $47.81 \pm 2.25 \mathrm{a}$ & $42.36 \pm 3.55 \mathrm{a}$ \\
Conventional & $9.0 \pm 2.09 \mathrm{a}$ & $24.56 \pm 3.97 \mathrm{a}$ & $30.67 \pm 5.28 \mathrm{a}$ & $46.20 \pm 2.16 \mathrm{a}$ & $43.50 \pm 1.66 \mathrm{a}$ \\
$\mathrm{CV}(\%)$ & 33.89 & 47.36 & 90.61 & 15.22 & 23.01 \\
\hline
\end{tabular}

Different letters represent significant differences among treatments by Tukey test $(\mathrm{p}<0.05)$. 


\subsection{Indirect Effect of Bt Cotton and No Bt Cotton Plants on the Immature and Adult Stages of $P$. nigrispinus}

No significant differences were observed for the duration of all periods of $P$. nigrispinus nymphs when they were raised on $S$. frugiperda larvae that had previously been fed on Bt cotton or no Bt cotton plants (Table 3). Likewise, the viability of the four nymph stages and the longevities of the predator males and females were not influenced when it was raised in caterpillars that previously fed on Bt cotton or no Bt cotton.

Differences between the two treatments evaluated for longevity of P. nigrispinus males and females were not observed either (Table 4). As it could be observed, the female longevity was very low, of only 8,0 and 7,4 days in the Bt cotton and no Bt cotton respectively (Table 4), and, therefore, it was not possible to evaluate the predator's reproduction parameters.

\section{Discussion}

\subsection{Direct Effect of Bt Cotton and No Bt Cotton Plants on the Im- mature and Adult Stages of the Predator P. nigrispinus}

It was observed a longer duration of the $P$. nigrispinus second instar of development when the insect was kept in direct contact with the Bt cotton plants. This difference observed for the second instar in the development can be attri

Table 3. Duration (days) and nymphal viability (\%) of $P$. nigrispinus when reared on $S$. frugiperda caterpillars previously fed with Bt cotton and no Bt cotton in the laboratory. Dourados, MS.

\begin{tabular}{|c|c|c|c|c|c|}
\hline & \multicolumn{5}{|c|}{ Stages of development } \\
\hline Treatments & $2^{\circ}$ instar & $3^{\circ}$ instar & $4^{\circ}$ instar & $5^{\circ}$ instar & Total \\
\hline $\mathrm{Bt}$ & $3.07 \pm 0.15 a$ & $4.47 \pm 0.29 a$ & $4.60 \pm 0.35 a$ & $6.74 \pm 0.41 \mathrm{a}$ & $18.68 \pm 0.99 \mathrm{a}$ \\
\hline Conventional & $3.23 \pm 0.13 a$ & $3.83 \pm 0.20 \mathrm{a}$ & $4.92 \pm 0.30 \mathrm{a}$ & $7.11 \pm 0.43 a$ & $19.61 \pm 0.64 \mathrm{a}$ \\
\hline \multirow[t]{2}{*}{$\mathrm{CV}(\%)$} & 11.62 & 15.98 & 17.64 & 13.76 & 9.82 \\
\hline & \multicolumn{5}{|c|}{ Nymphal viability (\%) } \\
\hline Treatments & $2^{\circ}$ instar & \multicolumn{2}{|c|}{$3^{\circ}$ instar } & instar & $5^{\circ}$ instar \\
\hline $\mathrm{Bt}$ & $100 \mathrm{a}$ & \multicolumn{2}{|c|}{$100 \mathrm{a}$} & $83.3 \mathrm{a}$ & $63.3 \mathrm{a}$ \\
\hline Conventional & $100 \mathrm{a}$ & \multicolumn{2}{|c|}{$100 \mathrm{a}$} & $86.6 a$ & $60.0 \mathrm{a}$ \\
\hline
\end{tabular}

Different letters represent significant differences among treatments by Tukey test $(\mathrm{p}<0.05)$

Table 4. Longevity (days) of males and females of $P$. nigrispinus when reared on $S$. frugiperda caterpillars previously fed with Bt cotton and no Bt cotton. Dourados, MS.

\begin{tabular}{ccc}
\hline Treatments & Female Longevity & Male Longevity \\
\hline Bt & $8.00 \pm 2.67 \mathrm{a}$ & $15.75 \pm 0.56 \mathrm{a}$ \\
Conventional & $7.40 \pm 1.72 \mathrm{a}$ & $14.20 \pm 3.40 \mathrm{a}$ \\
$\mathrm{CV}(\%)$ & 43.78 & 20.12 \\
\hline
\end{tabular}

Different letters represent significant differences among treatments by Tukey test $(\mathrm{p}<0.05)$. 
buted according to [15], to the beginning of the predator feeding stage when food may or may not be adequate and make the insect more dependent on the diet previously used. This observation is also reported by [16] who observed that the duration of the first predator $P$. nigrispinus nymphal stages is influenced by the type of food offered and emphasized that the nymphs can obtain a source of water and nutrients that promote its development from the cotton leaves. This difference in behavior may also justify the lower survival for the predator's second instar in Bt cotton and no Bt cotton, which were 80 and $90 \%$, respectively, while for the other instars it was $100 \%$. Insects, especially from the first instars, may require a period of time to adapt to the new diet, and this adaptation period may interfere with their development period and survival. However, no influence was observed between Bt cotton and no Bt cotton plants on the survival of different stages of predator nymphs (Table 1).

The phytophagy behavior of the predator may indicate improvements in its biological characteristics, such as a better nymphal development. However, although the predator receives the direct effect of the plants on their biological characteristics, it can't develop in the absence of prey [15]. Therefore, It can't be affirmed that this effect on the nymphal development period is due to the acquisition of the CrylAc toxin by the predator in the plant through the suction of it in search of water or nutrients. Although, the development and reproduction may be affected, due to ingestion of some poisonous substances present in these resistant plants [17]. It has been found in several works that the Cry1Ac protein can be detected in the body of non-target arthropods. However, these toxins have low or no effect on the biological parameters of these predators [8] [13] [18], corroborating the results of this work.

\subsection{Indirect Effect of Bt Cotton and No Bt Cotton Plants on the Immature and Adult Stages of the Predator P. nigrispinus}

For the indirect effect of the Bt cotton and no Bt cotton plants on $P$. nigrispinus, no significant differences were observed for instars duration and for the total nymphal development period of the predator. However, the longevity of adults was significantly lower when compared to the longevity of the adults obtained in the direct effect experiment. [19] also observed a negative effect on longevity, reproduction and viability of $P$. nigrispinus when the predator fed on prey fed on Bt cotton plants. This low longevity in the indirect effect experiment was probably due to the food quality provided to the predators, since in the first case (direct effect) T. molitor pupae were offered, while in the second experiment (indirect effect) were offered $\mathcal{S}$. frugiperda caterpillars fed on transgenic and no Bt cotton leaves were offered. According to [9] the prey feeding on plants expressing Bt protein, has nutritional deficiency when ingesting transgenic tissue, as may have occurred with the $S$. frugiperda caterpillars of this work. Consequently, the predator feeding on this prey with low nutritional quality had its metabolism affected, impairing its reproduction and longevity, although it was not verified in the present study that these toxins had an effect on the predator 
biological parameters. [20] found that the predator Cycloneda sanguinea (Linnaeus) presented lower larval stage duration and greater adult longevity when raised on $A$. gossypii that had been fed on Bt NuOPAL cotton cultivars, compared to the aphid developed in no Bt cotton. [21], studying the lethal or sub-lethal effects of toxins on the predator $C$. sanguinea, found that the Cry1Ac toxin, alone or in combination with the Cry1F toxin, had no effect on the predator with the concentrations tested under laboratory conditions, agreeing with the results of this work. On the other hand, [20] evaluated biological aspects of the predator $C$. sanguinea when raised with $A$. gossypii nymphs and adults fed on Bt NuOPAL cotton and no Bt Delta OPAL cotton cultivars. The authors observed that the predator, when fed with aphids raised on the transgenic Bt NuOPAL cotton cultivar, presented shorter larval stage duration, longer longevity and reproductive period compared to no Bt cotton (Delta OPAL).

It should be considered that the action of Bt cotton and no Bt cotton on $P$. nigrispinus adults in both the direct and indirect effect trials were cumulative and also due to the action of these plants on the predator immature stage, since the adults used in the trials were originated from the respective Bt cotton and no Bt cotton breeds. It is expected that with the predator's development there is a concentration of the Bt toxin in its body, since they are bred in prey that have developed in Bt cotton plants, as already observed in other works [7] [8].

Unlike the direct effect of the cotton on the predator, the lowest viability of nymphs in the indirect effect trial was observed for the last stages of development, reaching 63.3 and $60 \%$, respectively, of viability for the fifth instar in the Bt cotton and no Bt cotton (Table 3). This lower viability observed in the last nymphal stages could be due to the accumulation of Bt toxin in the body of the predator, although this analysis was not performed for this hypothesis to be confirmed. However, predators bred on prey that fed on no Bt cotton have also reduced viability in the last nymphal instars, which reinforces the thesis that the predator feeding on this prey with poor nutritional quality probably affected the predator's metabolism and longevity.

Considering all the evaluated biological parameters of $P$. nigrispinus both for the direct or indirect effect of the Bt cotton and no Bt cotton, it can be inferred that, generally speaking, the Bt cotton plants, that express the CrylAc toxin, has no interference with the predator's biology and reproduction. Other studies in the literature studying the indirect effect of corn, soybean or Bt cotton showed that Bt plants, also had no effect on the biology and behavior of the predators studied [3] [10] [19] [22] [23] [24].

\section{Conclusion}

Biology and reproduction of $P$. nigrispinus are not influenced when this predator is maintained in direct or indirect contact with Bt cotton plants expressing the Cry1Ac toxin. 


\section{Acknowledgements}

To the FUNDECT for providing the resources for the development of this project. To the Embrapa Agropecuária Oeste for providing the physical and personal structure for the work to be developed and to $\mathrm{CNPq}$ for granting the scholarship.

\section{References}

[1] James, C. (2013) Global Status of Commercialized Biotech/GM Crops: 2011. http://www.isaaa.org/resources/publications/briefs/43/executivesummary/.

[2] ISAAA (2015) Biotech Information Resources: ISAAA Brief 49-2014: Infographics. [S.L.] http://www.isaaa.org/resources/publications/briefs/49/infographic/default.asp

[3] Zhang, G.F., Wan, F.H., Murphy, S.T., Gou, J.Y. and Liu, W.X. (2008) Reproductive Biology of Two Non-Target Insect Species, Aphis gossypii (Homoptera: Aphididae) and Orius sauteri (Hemiptera: Anthocoridae), on Bt and Non-Bt Cotton Cultivars. Environmental Entomology, 37, 1035-1042.

[4] Ponsard, S., Gutierrez, A.P. and Mills, N.J. (2002) Effect of Bt-Toxin (Cry1Ac) in Transgenic Cotton on the Adult Longevity of Four Heteropteran Predators. Environmental Entomology, 31, 1197-1205. https://doi.org/10.1603/0046-225X-31.6.1197

[5] Mendes, S.M., Waquil, J.M., Marucci, R.C. and Boregas, K.G.B. (2009) Avaliação da incidência de organismos alvo e não alvo em milho Bt (CrylAb) em condições de campo em Sete Lagoas-MG. Embrapa Milho e Sorgo, Sete Lagoas (Circular Técnica, 128).

[6] Yano, S.A.C., Santana, G.K.S., Neiva, M.M., Moscardi, F., Martinelli, S. and Sosa-Gómez, D.R. (2012) Tolerância de Anticarsia gemmatalis Hübner, Pseudoplusia includens (Walker) e Rachiplusia nu (Guenée) à proteína Cry1Ac. In: CONGRESSO BRASILEIRO DE SOJA, 6, Cuiabá: CD-Rom. Cuiabá: Embrapa Soja.

[7] Zhang, G.F., Wan, F.H., Lovei, G.L., Liu, W.X. and Gou, J.Y. (2006) Transmission of Bt Toxin to the Predator Propylaea japonica (Coleoptera: Coccinellidae) through Its Aphid Prey Feeding on Transgenic Bt Cotton. Environmental Entomology, 35, 143-150. https://doi.org/10.1603/0046-225X-35.1.143

[8] Torres, J.B. and Ruberson, J.R. (2008) Interações de Bacillus thuringiensis Cry1Ac Toxin in Genetically Engineered Cotton with Predatory Heteropterans. Transgenic Research, 17, 345-354. https://doi.org/10.1007/s11248-007-9109-8

[9] Hilbeck, A., Baumgartner, M., Fried, P.M. and Bigler, F. (1998) Effects of Transgenic Baccillus thuringiensis Corn-Fed Prey on Mortality and Development Time of Immature Crysoperla carnea (Neuroptera: Chrysopidae). Environmental Entomology, 27, 480-487. https://doi.org/10.1093/ee/27.2.480

[10] Filho, A.B.E., Oliveira, J.V., Torres, J.B. and Gondim Jr., M.G.C. (2010) Biologia comparada e comportamento de Tetranychus urticae Koch (Acari: Tetranychidae) e Phytoseiulus macropilis (Banks) (Acari: Phytoseiidae) em algodoeiro Bollgard isolinha não-transgênica. Neotropical Entomology, 39, 338-344.

https://doi.org/10.1590/S1519-566X2010000300005

[11] Araújo, L.F., Silva, A.G., Cruz, I., Carmo, E.L., Neto, A.H., Goulart, M.M.P. and Rattes, J.F. (2011) Flutuação populacional de Spodoptera frugiperda (J. E. Smith), Diatraea saccharalis (Fabricius) e Doru luteipes (Scudder) em milho convencional e transgênico Bt. Revista Brasileira de Milho e Sorgo, 10, 205-214. https://doi.org/10.18512/1980-6477/rbms.v10n3p205-214 
[12] De Clercq, P., Mohaghegh, J. and Tirry, L. (2000) Effect of Host Plant on the Functional Response of the Predator Podisus nigrispinus (Heteroptera: Pentatomidae). Biological Control, 18, 65-70.

[13] Torres, J.B., Ruberson, J.R. and Adang, M.J. (2006) Expression of Bacillus thuringiensis Cry1 Ac Protein in Cotton Plants, Acquisition by Pests and Predators: A Tritrophic Analysis. Agricultural and Forest Entomology, 8, 191-202. https://doi.org/10.1111/j.1461-9563.2006.00298.x

[14] Pires, C.S.S., Fontes, E.M.G. and Sujii, E.R. (2003) Avaliação ecológica de risco de plantas geneticamente modificadas resistentes a insetos sobre inimigos naturais. In: Pires, C.S.S., Fontes, E.M.G. and Sujii, E.R., Eds., Impacto ecológico de plantas geneticamente modificadas: $O$ algodão resistente a insetos como estudo de casos, Embrapa, Brasília, 85-115.

[15] Oliveira, J.E.M., Torres, J.B., Carrano-Moreira, A.F. and Barros, R. (2002) Efeito das plantas do algodoeiro e do tomateiro, como complemento alimentar, no desenvolvimento e na reprodução do predador Podisus nigrispinus (Dallas) (Heteroptera: Pentatomidae). Neotropical Entomology, 31, 101-108. https://doi.org/10.1590/S1519-566X2002000100014

[16] Lemos, W.P., Medeiros, R.S., Ramalho, F.S. and Zanuncio, J.C. (2001) Effects of Plant Feeding on the Development, Survival and Reproduction of Podisus nigrispinus (Dallas) (Heteroptera: Pentatomidae). International Journal of Pest Management, 47, 89-93. https://doi.org/10.1080/09670870151130499

[17] Neto, F.C.M., Zanuncio, J.C., Picanço, M.C. and Cruz, I. (2002) Reproductive Characteristics of the Predator Podisus nigrispinus Fed with Insect Resistant Soybean Variety. Pesquisa Agropecuária Brasileira, 37, 917-924. https://doi.org/10.1590/S0100-204X2002000700004

[18] Torres, J.B. and Ruberson, J.R. (2006) Interaction of Bt-Cotton and the Omnivorous Big-Eyed Bug Geocoris punctipes (Say), a Key Predator in Cotton Fields. Biological Control, 39, 47-57.

[19] Jesus, F.G., Boiça-Junior, A.L., Alves, G.C.S. and Zanuncio, J.C. (2014) Behavior, Development and Predation of Podisus nigrispinus (Hemiptera: Pentatomidae) on Spodoptera frugiperda (Lepidoptera: Noctuidae) Fed Transgenic and No Bt Cotton Cultivars. Annals of the Entomological Society of America, 107, 601-606. https://doi.org/10.1603/AN13100

[20] Funichello, M., Costa, L.L., Gil, O.J.A. and Busoli, A.C. (2012) Aspectos biológicos de Cycloneda sanguínea (Coleóptera: Coccinellidae) alimentadas com pulgones criados em algodón transgénico Bollgard. Revista Colombiana de Entomologia, 38, 156-161.

[21] Bellinati, A.R. (2013) Método para avaliação de risco ambiental de toxinas Bt sobre organismos não-alvo em laboratório: Foco no predador Cycloneda sanguínea (Coleoptera: Coccinellidae). Dissertação (Mestrado em Ecologia), Universidade de Brasília.

[22] Zwahlen, C., Nentwig, W., Bigler, F. and Hilbeck, A. (2000) Tritrophic Interactions of Transgenic Bacillus thuringiensis Corn, Anaphothrips obscurus (Thysanoptera: Thripidae), and the Predator Orius majusculus (Heteroptera: Anthocoridae). Environmental Entomology, 29, 846-850. https://doi.org/10.1603/0046-225X-29.4.846

[23] Veiga, A.C.P. (2011) Características biológicas de Orius insidiosus alimentado com Aphis gossypii em algodão transgênico e convencional. Dissertação (Mestrado em Agronomia), UNESP, Faculdade de Ciências Agrárias e Veterinárias.

[24] Mendes, S.M., Brasil, K.G.B., Waquil, M.S., Marucci, R.C. and Waquil, J.M. (2012) 
Biologia e comportamento do percevejo predador, Orius insidiosus (Say, 1832) (Hemiptera: Anthocoridae) em milho Bt e não Bt. Bioscience Journal, 28, 753-761.

Submit or recommend next manuscript to SCIRP and we will provide best service for you:

Accepting pre-submission inquiries through Email, Facebook, LinkedIn, Twitter, etc. A wide selection of journals (inclusive of 9 subjects, more than 200 journals)

Providing 24-hour high-quality service

User-friendly online submission system

Fair and swift peer-review system

Efficient typesetting and proofreading procedure

Display of the result of downloads and visits, as well as the number of cited articles Maximum dissemination of your research work

Submit your manuscript at: http://papersubmission.scirp.org/

Or contact ajps@scirp.org 